\title{
Is back pain a diagnostic problem in clinical practices? A rare case report
}

\author{
Sırt ağrısı klinik uygulamalarda diyagnozu sorun mu? \\ Nadir bir olgu sunumu
}

Selçuk GÖÇMEN, ${ }^{1}$ Ahmet ÇOLAK, ${ }^{2}$ Burcu MUTLU, ${ }^{3}$ Abdulkadir ASAN ${ }^{4}$

\begin{abstract}
Summary
Multiple thoracic disc herniations are rare, and few reports exist in the literature. Diagnosis of these herniations is often missed because of their lack of specific clinical presentation. They may be treated conservatively or surgically. We presented a 35-yearold woman with five contiguous level thoracic disc herniations. She was admitted with upper back pain. Magnetic resonance imaging showed disc herniations at levels T6-7, T7-8, T8-9, T9-10 and T10-11. All were left sided and on the same line in the sagittal plane. The patient underwent conservative treatment. This report presented an unusual case and discussed its mechanisms.
\end{abstract}

Key words: Magnetic resonance imaging; multiple disc herniations; pain; thoracic disc herniation.

\begin{abstract}
Özet
Çok seviyeli torakal disk hernileri nadirdir ve literatürde az sayıda yayın vardır. Çok seviyeli torakal disk hernilerinin spesifik klinik tablosu olmadığı için, tanısı genellikle gözden kaçar. Biz beş komşu seviyeli torakal disk hernisi olan 35 yaşında bir kadın hasta sunduk. Hasta üst sırt ağrısı ile başvurdu. Manyetik rezonans görüntüleme T6-7, T7-8, T8-9, T9-10 ve T10-11 seviyelerinde disk hernilerini gösterdi. Tüm disk hernileri sagittal planda sol tarafta ve aynı hatta dizilmişti. Hastaya konservatif tedavi uygulandı. Bu yazıda sıradışı bir olgu sunduk ve mekanizmalarını tartıştık.

Anahtar Kelimeler: Manyetik rezonans görüntüleme; çok seviyeli disk hernileri; ağrı; torakal disk hernisi.
\end{abstract}

\section{Introduction}

The incidence of thoracic disc herniation is reported to be one per million per year. ${ }^{[1]}$ It represents between $0.5 \%$ and $4.5 \%$ of all disc herniations and between $0.15 \%$ and $1.8 \%$ of all surgically-treated herniations. ${ }^{[1]}$ Both sexes are affected equally and it is more common between the fourth and sixth decades with a peak in the fourth decade. ${ }^{[2]}$ Multiple thoracic disc herniations are rare clinical entities and remarkable. ${ }^{[1]}$ We present an unusual case and discuss the mechanisms.

\section{Case Report}

A 33-year-old female admitted with 6 months history of severe thoracic back pain in our clinics. She evaluated by different clinicians, but the diagnosis did not find. The painkillers were given by clinicians but she did not improved. She is a housewife and has no history of trauma. In neurological examination, there was no motor and sensory deficit or bladder or bowel dysfunction. Blood, biochemical, and urine analyses revealed no abnormalities. Plain radiography showed slight scoliosis, but no other abnormali-

\footnotetext{
'Department of Neurosurgery, Gulhane Military Medical Academy, Haydarpasa Training Hospital, Istanbul, Turkey

${ }^{2}$ Department of Neurosurgery, Medical Park Hospital, Elazig, Turkey

${ }^{3}$ Department of Physical Medicine and Rehabilitation, Nisa Hospital, Istanbul, Turkey

${ }^{4}$ Department of Radiology, Nisa Hospital, Istanbul, Turkey

Submitted (Başvuru tarihi) 08.11.2013 Accepted after revision (Düzeltme sonrası kabul tarihi) 11.03.2014

Correspondence: Dr. Selçuk Göçmen. Tıbbiye Caddesi, Selimiye Mahallesi, Üsküdar, İstanbul, Turkey.

Tel: +90 - 216 - 5422020 / 4107 e-mail:s_gocmen@yahoo.com

(C) 2015 Turkish Society of Algology
} 
ties. Magnetic resonance imaging (MRI) revealed left paracentral disk protrusions with annular tear at the levels of T6-7, T7-8, T8-9, T9-10, and left paracentral disk bulging at the level of T10-11 (Fig. 1). All these herniations were left sided and on the same line in sagittal plane (Fig. 1). The patient underwent physical therapy and follow-up. Surgery is not needed, now.

\section{Discussion}

Multiple thoracic disc herniations are rare; the condition was first reported by Svien and Karavits in 1954. [2] The diagnosis of thoracic disc herniation may increase after widespread use of MRI. ${ }^{[3]}$ Linscott MS et al have reported that $26 \%$ of the patients had multiple thoracic herniations and $12 \%$ of patients had disk protrusions at non-contiguous levels in a study of 78 cases of thoracic disk herniations. ${ }^{[4]}$ Sari et al. have reported a case similar to our case. ${ }^{[5]}$

The clinical symptoms of thoracic disc herniation are variable. Some patients are asymptomatic, while others have midline thoracic pain, girdle pain or myelopathy. ${ }^{[1]}$ Because there are no characteristic symptoms and thoracic spinal disc herniation is relatively rare, the diagnosis can be difficult. ${ }^{[1]}$ Back pain is the most common presenting symptom and weakness is the most common physical finding. ${ }^{[4,5]}$

Multiple thoracic disc herniations may be seen at every level, but they are most commonly located in the lower thoracic spine with more than $75 \%$ occurring below T8, mainly at T11/12. ${ }^{[1-3]}$ This appears to be the result of weakness of the posterior longitudinal ligament and increased motion of the lower thoracic segment. ${ }^{[1,3-5]}$ In adults, the intra-articular ligament extends within the costovertebral joint from the rib head to the adjacent intervertebral disc. ${ }^{[3]}$ This ligament has a vestigial nature. The intra-articular ligament is absent at the $1^{\text {st }}, 10^{\text {th }}, 11^{\text {th }}$, and $12^{\text {th }}$ costovertebral joints. ${ }^{[3]}$ In addition, the ratio of the diameter of the spinal cord to that of the spinal canal in the thoracic spine is large and the blood supply in this region is limited. ${ }^{[1]}$ This makes the spinal cord vulnerable to compression from disc herniation. ${ }^{[1]}$ The diagnosis of a thoracic disc herniation can be difficult as there is no characteristic pattern of the onset of symptoms.

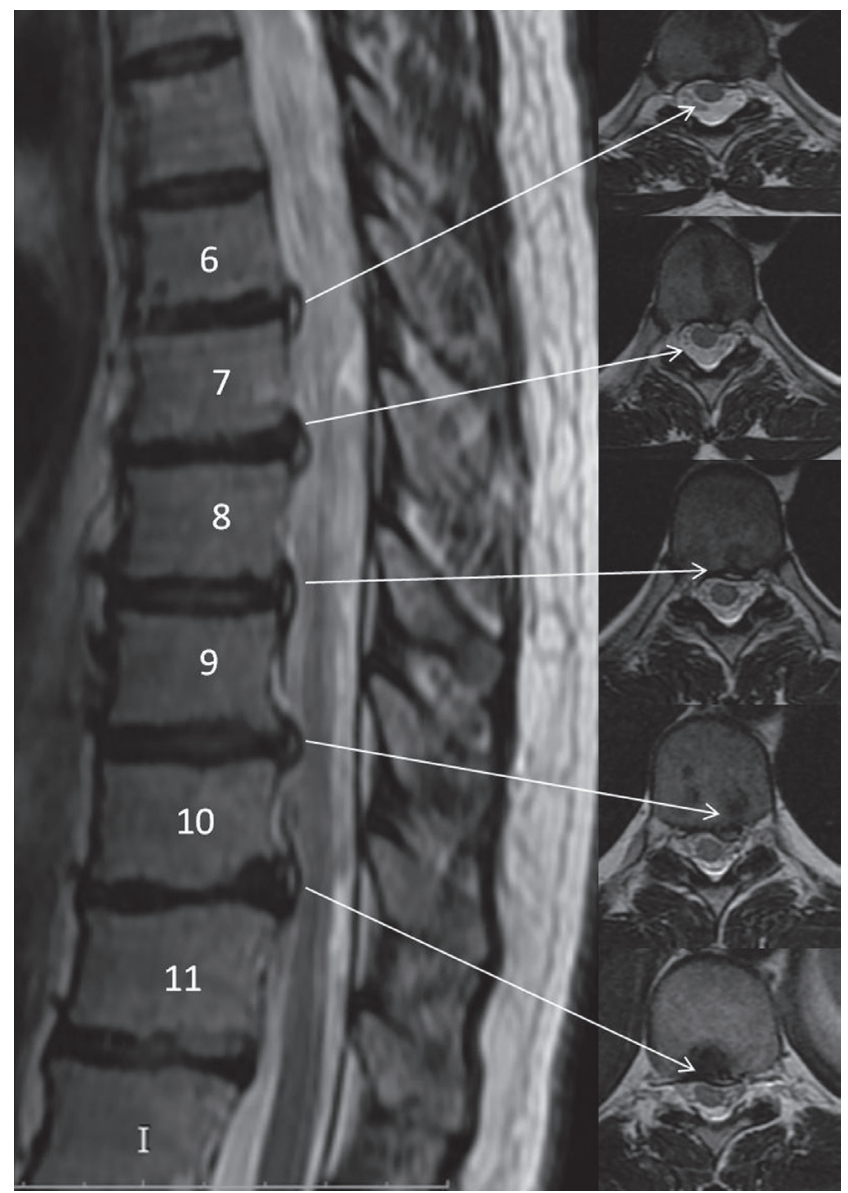

Figure 1. T2-weighted sagittal and axial MRI demonstrates multiple thoracic disc herniations at T6-7, T7-8, T8-9, T9-10, and T1011 levels. Arrows indicate the axial cross sections of the pathologic levels.

Some researchers have shown that conservative treatment is effective for patients without long-tract clinical signs. ${ }^{[1]}$ However, surgical treatment is required for patients with myelopathy. ${ }^{[1]}$ Various surgical approaches for thoracic disc herniations, such as anterior (transternal and transthoracic disc excision), posterior (pediculofacetetctomy) and lateral (lateral costotransversectomy and lateral extracavitary), the posterolateral approach and laminectomy without discectomy, have been described, together with their respective advantages and disadvantages, as well as limitations of the exposed area. ${ }^{[3,6]}$

The diagnosis of multiple thoracic disc herniations is often missed because they have no characteristic symptoms. The presented case with contiguous multiple thoracic disk herniations is an unusual condition. Every patient with thoracic back pain should be well evaluated by neuro-radiological examinations. 
Conflict-of-interest issues regarding the authorship or article: None declared.

\section{Peer-rewiew: Externally peer-reviewed.}

\section{References}

1. Ohnishi K, Miyamoto K, Kanamori Y, Kodama H, Hosoe $\mathrm{H}$, Shimizu K. Anterior decompression and fusion for multiple thoracic disc herniation. J Bone Joint Surg $\mathrm{Br}$ 2005;87(3):356-60.

2. Okada Y, Shimizu K, Ido K, Kotani S. Multiple thoracic disc herniations: case report and review of the literature. Spinal Cord 1997;35(3):183-6.

3. Peker S, Akkurt C, Ozcan OE. Multiple thoracic disc herniations. Acta Neurochir (Wien) 1990;107(3-4):167-70.

4. Linscott MS, Heyborne R. Thoracic intervertebral disk herniation: a commonly missed diagnosis. J Emerg Med 2007;32(3):235-8.

5. Sari H, Uludag M, Gun K, Mogulkoc N, Gokpinar HH. Multilevel thoracic disk herniations in a young woman. Am J Phys Med Rehabil 2013;92(6):551.

6. O'Connor RC, Andary MT, Russo RB, DeLano M. Thoracic radiculopathy. Phys Med Rehabil Clin N Am 2002;13(3):62344. 